\title{
Arti Penting Perlindungan Merek Terdaftar Bagi Komunitas Penghasil Produk Ekonomi Kreatif
}

\author{
Wizna Gania Balqis ${ }^{1 *}$, Budi Santoso² \\ 1Program Studi Magister Ilmu Hukum, Fakultas Hukum, Universitas Diponegoro \\ 2Fakultas Hukum, Universitas Diponegoro \\ wwngania@gmail.com
}

\begin{abstract}
Creative Economy is an economic activity that comes from the use of creativity, skills and talents of individuals in terms of creating prosperity and opening jobs by producing and exploiting individual creative and creative power. In the world of commerce, the business sector in every business must have intellectual property in it, including products produced by the creative economy community which generally have a trademark. However, most of the ecographers have not registered their product brands, so it is deemed necessary to research the importance of protecting registered brands for the creative economy product-producing community. This research is a doctrinal research, which is a study that uses an empirical juridical approach where the research is conducted at the Ministry of Law and Human Rights of Central J ava Province, the Office of Cooperatives and UMK Semarang City and the community of creative economy practitioners in the City of Semarang. This research shows that the Brand as one of the Intellectual Property Rights which has an important role in trading activities in order to avoid unfair business competition, this is because the presence of a brand can be used as a sign to distinguish a product from other products. Legal protection for brands needs to be provided through preventive protection and repressive legal protection. There are obstacles in the implementation of trademark registration in the creative economy products both experienced by the creative economy actors and related institutions that include internal barriers and external barriers as well as efforts to overcome them.
\end{abstract}

\section{Keywords: Protection; Registered Trademark; Community; Creative Economy.}

\begin{abstract}
ABSTRAK
Ekonomi Kreatif merupakan kegiatan perekonomian yang berasal dari pemanfaatan kreativitas, keterampilan dan bakat individu dalam hal untuk menciptakan kesejahteraan serta membuka lapangan pekerjaan dengan cara menghasilkan dan mengeksploitasi daya kreasi dan daya cipta individu. Dalam dunia perdagangan, sektor bisnis pada setiap usahanya pasti memiliki kekayaan intelektual didalamnya, termasuk produk-produk yang dihasilkan oleh komunitas ekonomi kreatif yang pada umumnya mempunyai suatu merek dagang. Namun sebagian besar pelaku ekraf belum mendaftarkan merek produknya, maka dipandang perlu penelitian tentang arti penting perlindungan merek terdaftar bagi komunitas penghasil produk ekonomi kreatif. Penelitian ini merupakan penelitian doktrinal, yaitu penelitian yang menggunakan pendekatan yuridis empiris dimana penelitian dilakukan di di Kementerian Hukum dan Hak Asasi Manusia Provinsi Jawa Tengah, Dinas Koperasi dan UMK Kota Semarang dan komunitas pelaku ekonomi kreatif di Kota Semarang. Penelitian ini menunjukkan bahwa Merek sebagai salah satu Hak Kekayaan Intelektual yang mempunyai peran penting dalam kegiatan perdagangan guna menghindari persaingan usaha yang tidak sehat, hal ini disebabkan karena dengan adanya merek dapat dijadikan sebagai tanda untuk membedakan suatu produk dengan produk lainnya. Perlindungan hukum terhadap merek perlu diberikan melalui perlindungan secara preventif dan perlindungan hukum secara represif. Terdapat hambatan-hambatan dalam implementasi pendaftaran merek pada produk ekonomi kreatif baik yang dialami oleh perlaku ekonomi kreatif maupun instansi terkait yakni meliputi hambatan internal dan hambatan ekternal serta uapaya dalam mengatasinya.
\end{abstract}

Kata Kunci: Perlindungan; Merek Terdaftar; Komunitas; Ekonomi Kreatif. 
Jurnal Pembangunan Hukum Indonesia

Volume 2, Nomor 2, Tahun 2020
Program Studi Magister Ilmu Hukum Fakultas Hukum Universitas Diponegoro

\section{A. PENDAHULUAN}

Ekonomi Kreatif (ekraf) merupakan golongan kelompok industri yang didalamnya terdiri atas berbagai macam industri dimana saling berkaitan dalam proses guna mewujudkan suatu ide atau gagasan yang dituangkan menjadi sebuah kekayaan intelektual (intellectual property) yang memiliki nilai ekonomi tinggi dalam mewujudkan kesejahteraan dan lapangan kerja bagi masyarakat luas serta agar pertumbuhan ekonomi suatu negara dapat meningkat. Ekraf dapat juga menciptakan suatu peluang bagi masyarakat dimana dengan adanya ekraf ini diharapkan masyarakat dapat mengembangkan usahanya dengan memanfaatkan sumber daya yang tidak hanya mengandung unsur kebaruan saja, tetapi juga tidak terbatas, yakni ide, talenta dan kerativitas (Rosmadi, 2014). Sasaran yang akan dicapai oleh Ekonomi Kreatif yakni dalam hal peningkatan laju pertumbuhan, membuka lapangan pekerjaan dan meningkatkan angka pendapatan yang bmempunyai sifat kreatif, langka, dan belum banyak dilakukan oleh orang lain, memiliki daya jual serta pangsa pasar domestik dan ekspor yang luas (Rois, \& Roisah, 2018).

Produk ekonomi kreatif sebagai suatu kekayaan intelektual yang dihasilkan dan dimiliki oleh seorang pencipta baik di bidang seni, sastra, ilmu pengetahuan maupun teknologi (Rongiyati, 2018). Maka dari itu, sudah selayaknya perlu diberikan suatu penghargaan dari negara pada produk ekonomi kreatif sebagai suatu karya dengan nilai ekonomi yang tinggi dan harus mendapatkan perlindungan terhadap hak kekayaan intelektualnya. Perlindungan tersebut diberikan agar seorang pencipta atau penemu ide kreatif mendapatkan manfaat ekonomi yang dihasilkan dari karya intelektualnya tersebut. Walaupun telah diatur dalam peraturan perundang-undangan, namun pada kenyataannya kesadaran mengenai perlindungan HKI di Indonesia masih terbilang rendah. Dapat dilihat bahwa saat ini masih rendahnya produkproduk ekonomi kreatif yang didaftarkan di Dirjen Kekayaan Intelektual. Selain itu, angka pembajakan atau plagiat terhadap suatu karya atau ide kreatif ini sangat merugikan pencipta produk ekonomi kreatifnya terutama dalam hal pemenuhan hak ekonomi penciptanya masih terbilang sangat tinggi. Hal ini disebabkan karena pandangan mengenai realitas perlindungan $\mathrm{HKI}$ terkait dengan prosedur pendaftaran HKI dianggap rumit, sulit, membutuhkan biaya yang besar dengan waktu yang lama dan tidak pasti.

Dalam dunia perdagangan, sektor bisnis sudah pasti pada setiap usahanya memiliki kekayaan intelektual didalamnya yang harus dilindungi. Sama halnya dengan produk-produk ekraf yang menjadi obyek dalam penelitian ini yakni produk-produk ekraf dengan merek Praba Cempaka, Kidung Bracelet, Bel_Incraft dan Pipimerah_id. Produk-produk ekraf tersebut masuk dalam subsector Kriya atau kerajinan tangan. Pemilik produk-produk ekraf tersebut belum mendaftarkan merek dagangnya. Hanya produk Praba Cempaka yang sedang dalam proses pendaftaran merek namun hingga saat pemilik merek 
Jurnal Pembangunan Hukum Indonesia

Volume 2, Nomor 2, Tahun 2020
Program Studi Magister Ilmu Hukum Fakultas Hukum Universitas Diponegoro
Praba Cempaka tidak diberikan kejelasan mengenai pendaftaran mereknya. Hak atas merek yang dimiliki oleh seseorang atau badan hukum baru akan terjadi setelah merek tersebut terdaftar di Direktorat Jenderal Hak Kekayaan Intelektual (DJKI) Kementerian Hukum dan Hak Asasi Manusia. Hal ini sesuai dengan yang diatur dalam Pasal 3 dan Pasal 4 ayat (1) Undang-Undang No. 20 Tahun 2016 Tentang Merek dan Indikasi Geografis.

Implementasi pendaftaran merek pada produkproduk ekraf tidak terlepas dari suatu hambatanhambatan yang dihadapi baik oleh pelaku ekraf maupun Pemerintah dan Pemerintah Daerah yang mempunyai kewenangan dalam hal pendaftaran merek dagang. Dengan adanya hambatan-hambatan tersebut maka diperlukan adanya suatu upaya atau solusi guna mengatasi hambatan-hambatan dalam implementasi pendaftaran merek bagi komunitas penghasil produk ekraf. Hal ini diharapkan akan mendorong dan meningkatkan para pelaku ekraf untuk mendaftarkan merek produk ekrafnya. Mengingat bahwa roduk-produk ekraf sangat rentan dengan perilaku unfair competition. Itu sebabnya perlindungan hukum terhadap Hak Kekayaan Intelektual khususnya Merek di Indonesia menjadi permasalahan yang sangat penting.

Perlindungan hukum yang diberikan terhadap suatu merek dagang bukan hanya bertujuan untuk memberikan keuntungan pada pihak produsen tetapi juga untuk memberikan perlindungan pada pihak konsumen. Maka dari itu perlindungan terhadap suatu merek sudah seharusnya diatur dengan tegas supaya konsumen dapat terlindungi dari adanya pemalsuan barang atau jasa yang menggunakan suatu merek secara tidak sah.

Berdasarkan permasalahan mengenai arti penting perlindungan merek terdaftar bagi komunitas penghasil produk ekonomi kreatif ini menggunakan beberapa teori yang mendasari konsep hak kekayaan inteletual terutama mengenai merek. Satjipto Rahardjo dalam teori perlindungan hukum menjelaskan bahwa perlindungan merupakan upaya untuk melindungi kepetingan dari seseorang dengan cara mengalokasikan suatu Hak Asasi Manusia (HAM) kekuasaan kepadanya untuk bertindak dalam rangka kepentingannya tersebut (Rahardjo, 2010).

Dalam hal perlindungan terhadap merek pada produk-produk ekraf, dalam penelitian ini menggunakan teori perlindungan hak kekayaan intelektual di bidang merek yakni Risk Theory, Recovery Theory, Incentive Theory, Reward Theory, dan Economic Growth Stimulus Theory (Sherwood, 1990). Produk-produk ekonomi kreatif sebagian besar merupakan golongan Usaha Mikro dan Kecil (UMK) dimana karakteristik dari UMK adalah usaha yang mempunyai keterbatasan dalam hal keuangan, oleh karena itu sejalan dengan teori John Laws dimana ia mementingkan terjaminnya kesetaraan, kebebasan serta hak individu dalam kehidupan sosial, ekonomi dan politik. la juga memperhatikan kesejahteraan kelompok masyarakat yang lemah (Fauzan, \& Prastyo, 2006).

Pengembangan ekonomi kreatif di Indonesia merupakan bentuk optimisme serta aspirasi guna 
Jurnal Pembangunan Hukum Indonesia

Volume 2, Nomor 2, Tahun 2020
Program Studi Magister Ilmu Hukum Fakultas Hukum Universitas Diponegoro mendukung dalam perwujudan visi dari negara Indonesia itu sendiri yakni menjadi negara yang maju dengan pemikiran, cita-cita dan mimpi masyarakatnya agar bisa mendapatkan kehidupan yang layak dan berkualitas. Sumber daya manusia (SDM) dijadikan modal utama pada sebuah pengembangan ekonomi kreatif yang diawali dari gagasan, ide maupun pemikiran.

Perlindungan hukum yang diberikan terhadap suatu merek dagang pada produk-produk ekraf bukan hanya bertujuan untuk memberikan keuntungan pada pihak produsen tetapi juga untuk memberikan perlindungan pada pihak konsumen. Maka dari itu perlindungan terhadap suatu merek sudah seharusnya diatur dengan tegas supaya konsumen dapat terlindungi dari adanya pemalsuan barang atau jasa yang menggunakan suatu merek secara tidak sah. Perlindungan hukum terhadap merek terdaftar yang diberikan oleh negara diharapkan dapat mendorong minat bagi komunitas penghasil ekonomi ekraf untuk mendaftarkan merek produk ekrafnya, mengingat bahwa masih rendahnya kesadaran pelaku ekraf dalam mendaftarkan merek produk ekrafnya.

Namun yang menjadi permasalahan apakah perlindungan hukum yang diberikan oleh negara sudah diterapkan sesuai dengan ketentuan yang berlaku ataukah masih terdapat hambatan-hambatan dalam pelaksanaannya. Pentingnya penelitian tentang arti penting merek terdaftar bagi komunitas penghasil produk ekonomi kreatif ini adalah untuk mengetahui seberapa penting pendaftaran merek pada produk-produk ekraf bagi komunitas penghasil produk ekraf serta bagaimana implementasi mekanisme pendaftaran tersebut. Dalam hal implementasi pendaftaran merek tentunya terdapat berbagai hambatan yang dihadapi baik oleh pelaku ekraf itu sendiri maupun bagi instansi yang terkait dengan permasalahan pendaftaran merek, seperti halnya bahwa komunitas penghasil produk ekonomi kreatif mengeluhkan mengenai rumit dan lamanya proses pendafataran merek, selain itu mereka juga menganggap bahwa biaya pendaftaran merek terbilang mahal untuk usaha kecil sekelas mereka. Oleh karena itu, dengan adanya hambatan tersebut perlu adanya upaya yang harus dilakukan agar implementasi pendaftaran merek dapat dijalankan secara optimal.

Berdasarkan uraian latar belakang di atas, dalam penelitian ini terdapat pokok permasalahan yang akan dibahas, yakni sebagai berikut: 1). Bagaimana implementasi pendaftaran merek bagi komunitas penghasil produk ekonomi kreatif?; dan 2). Apa saja hambatan-hambatan yang dihadapi dalam perlindungan merek terdaftar bagi komunitas penghasil produk ekonomi kreatif dan bagaimana upaya dalam mengatasi hambatan-hambatan tersebut?.

Tujuan dari penelitian ini adalah cerminan dari pokok permasalah yang akan dibahas, yakni sebagai berikut: 1). Untuk mengetahui dan menganalisa bagaimana implementasi pendaftaran merek bagi komunitas penghasil produk ekonomi kreatif; dan 2). Untuk mengetahui dan menganalisa hambatan serta 
Jurnal Pembangunan Hukum Indonesia

Volume 2, Nomor 2, Tahun 2020
Program Studi Magister Ilmu Hukum

Fakultas Hukum Universitas Diponegoro upayanya dalam perlindungan merek terdaftar bagi komunitas penghasil produk ekonomi kreatif.

Mengingat penelitian yang berfokus pada Pentingnya Perlindungan HKI terhadap Merek Terdaftar Pada Produk Ekonomi Kreatif yang telah dilakukan sebelumnya seperti oleh Nia Kurniati dkk yang berfokus pada Perlindungan HKI terhadap produk Teri Biru Seira dan Kerupuk Ikan Tanimbar sebagai industri kreatif yang ada pada masyarakat Kota Sumlaki (Kurniati dkk, 2017); Agus Sardjono, Brian A. Prastyo dan Desrezka G. Larasati, yang berfokus pada implementasi perlindungan merek untuk pengusaha UKM batik di Pekalongan, Solo dan Yogyakarta (Sardjono, Prastyo \& Larasati, 2013); Irwan Yulianto dan Ali Uraidi, yang berfokus pada pelaksanaan perlindungan HKI guna meningkatkan potensi Batik (Yulianto \& Uraidi); Keisha LaRaine Ingram, yang berfokus pada Intellectual Property Protection for Brand Jamaica's Creative Industries yang membahas mengenai implementasi merek Jamaica di Industri Kreatif (Ingram, 2014); dan Stephanie M. Greene, yang berfokus pada perlindungan merek terkenal di China sebagai tantangan bagi pemegang merek asing (Greene, 2011).

Atas penelitian sebelumnya, terdapat perbedaan fokus penelitian yang akan dilakukan saat ini dengan penelitian yang sudah ada. Walaupun sama-sama mengambil tema tentang perlindungan $\mathrm{HKI}$, namun penelitian ini lebih menekankan pada perlindungan merek terdaftar bagi komunitas penghasil produk ekonomi kreatif, sehingga membuat pembahasan mengenai hal ini menjadi hal yang selalu penting dan aktual untuk dilakukan pengkajian.

\section{B. METODE PENELITIAN}

Pendekatan penelitian yang digunakan dalam penelitian ini adalah pendekatan yuridis empiris, yang mana penelitian ini akan dilakukan di Kantor Wilayah Kementerian Hukum dan HAM Provinsi Jawa Tengah, di Dinas Koperasi dan UMK Kota Semarang, serta pada beberapa komunitas pelaku ekonomi kreatif yang ada di Kota Semarang. Pendekatan yuridis atau pendekatan perundang-undangan adalah suatu penelitian yang berusaha meneliti hal-hal yang berkaitan dengan peraturan perundang-undangan. Pendekatan ini dimaksudkan menganalisis data sekunder yaitu berbagai peraturan terkait dengan arti penting perlindungan merek terdaftar bagi komunitas penghasil produk ekonomi kreatif. Sedangkan pendekatan empiris, digunakan untuk menganalisa pemberlakuan atau implementasi ketentuan hukum secara in action yang terjadi dalam masyarakat. Pendekatan ini menggunakan data primer yang diperoleh secara langsung pada objek penelitian yang berhubungan dengan arti penring perlindungan merek terdaftar bagi komunitas penhasil produk ekonomi kreatif. Dengan demikian pendekatan yuridis empiris adalah sebuah metode penelitian hukum yang berupaya untuk melihat hukum dalam artian yang nyata di masyarakat. 


\section{HASIL DAN PEMBAHASAN}

\section{Implementasi Pendaftaran Merek Pada} Komunitas Penghasil Produk Ekonomi Kreatif (ekraf)

Pada era perdagangan global saat ini, sejalan dengan telah diratifikasinya konvensi internasional oleh Indonesia, peranan merek menjadi sangat penting khususnya dalam hal guna menjaga persaingan usaha yang sehat, menjunjung tinggi keadilan, menjamin perlindungan terhadap konsumen, serta perlindungan terhadap Usaha Mikro dan Kecil (UMK) yang berbasis kreativitas serta industri kreatif dalam negeri lainnya. Dibentuknya Undang-Undang No. 20 Tahun 2016 tentang Merek dan Indikasi Geografis diharapkan dapat menjadi salah satu alternatif cara pemerintah dalam memberikan perlindungan terhadap pelaku ekraf yang sebagian besar tergolong dalam Usaha Mikro dan Kecil (UMK). Perlindungan yang diberikan khususnya melalui perlindungan kekayaan intelektual yang terdapat di dalam produk-produk ekraf yang berupa merek. Peneliti dalam melakukan penelitian ini menggunakan sampel tiga responden pelaku usaha ekraf di Kota Semarang. Merek produk-produk ekraf yang dimiliki oleh pelaku ekraf yang peneliti jadikan bahan penelitian yaitu Praba Cempaka, Kidung Bracelet, Bel_incraft dan Pipimerah_id.

Berdasarkan hasil wawancara yang telah dilakukan oleh peneliti, dapat menunjukkan bahwa memang pada kenyataannya masih banyak pelaku ekraf yang belum mendaftarkan merek produknya dan belum mengetahui secara luas mengenai pentingnya perlindungan merek terdaftar terhadap produk-produk ekraf miliknya. Hal ini diakibatkan karena minimnya pengetahuan mengenai pentingnya perlindungan Hak Kekayaan Intelektual terhadap merek dagangnya. Salah satu pelaku ekraf pemula yang menjadi responden dalam penelitian ini yakni pemilik merek Bel_Incraft mengungkapkan bahwa sebagian besar pelaku ekraf lebih memprioritaskan dengan menumbuhkan usahanya terlebih dulu, yang mereka pikirkan yaitu bagaimana cara agar usahanya bisa terus tumbuh, berkembang dan bisa dikenal banyak orang. Sedangkan mengenai pentingnya pendaftaran Hak Kekayaan Intelektual yang terkandung dalam mereknya bukan menjadi prioritasnya, walaupun pada dasarnya pelaku ekraf menyadari bahwa HKI itu merupakan hal yang penting dalam kegiatan usaha yang mereka miliki (Irawati, 2019). Usaha Mikro dan Kecil (UMK) sebagai suatu industri bersakala kecil, masih banyak pelaku usaha ekraf yang menganggap bahwa perlindungan terhadap kekayaan intelektual yang dimilikinya itu bukan merupakan suatu hal yang penting. Hal ini dapat dilihat bahwa sampai saat ini masih minimnya produk-produk ekraf yang telah didaftarkan ke Kemenkumham. Padahal menurut pandangan yang diberikan oleh World Intellectual Property Rights (WIPO), ekonomi kreatif berpotensi untuk tumbuh serta mengembangkan inovasi-inovasi dan kreativitas atas produk yang dihasilkannya. Namun sangat disayangkan bahwa pada kenyataannya kesadaran pelaku usaha ekraf akan pentingnya perlindungan Hak Kekayaan Intelektual 
Jurnal Pembangunan Hukum Indonesia

Volume 2, Nomor 2, Tahun 2020
Program Studi Magister Ilmu Hukum Fakultas Hukum Universitas Diponegoro khususnya dibidang merek guna mendukung kegiatan usaha mereka masih tergolong rendah (Sardjono, 2013).

Implementasi pendaftaran merek serta perlindungan hukum terhadap merek pada produkproduk ekraf di Kota Semarang yang menjadi sampel dalam penelitian ini merupakan suatu Usaha Mikro dan Kecil (UMK) yang menjadi binaan dari Pemerintah Daerah. Menurut Ibu Afwa selaku Staff Pengembangan, Penguatan dan Perlindungan Usaha Mikro di Dinas Koperasi dan UMK Kota Semarang mengatakan bahwa pihaknya memberikan bantuan dalam hal pengurusan syarat pembentukan usaha ekrafnya melalui pembuatan SIUP (Surat Izin Usaha Perdagangan) dan izin PIRT (Pangan Industri Rumah Tangga). Syarat-syarat ini harus ada jika nantinya pelaku usaha ekraf berniat ingin mendaftarkan mereknya melalui Pemerintah Daerah. Pemerintah Daerah juga menfasilitasi dalam pendaftaran merek produk-produk ekraf, namun saat ini hanya merek Praba Cempaka yang baru dalam proses pendaftaran merek.

Pendaftaran merek pada produk-produk ekraf yang tergolong Usaha Mikro dan Kecil (UMK) binaan pemerintah daerah harus sesuai dengan prosedur yang telah ditetapkan. Prosedur pendaftaran merek jika melalui Pemerintah Daerah hampir sama dengan jika mendaftar langsung melalui Kementerian Hukum dan HAM. Terdapat perbedaan dalam prosedur pendaftaran merek pada produk-produk ekraf yang menjadi binaan Pemerintah Daerah yaitu harus melalui prosedur seleksi atau peninjauan terlebih dahulu dari Dinas Koperasi dan UMK dan harus memenuhi syarat-syarat yang telah ditetapkan. Menurut Ibu Afwa, syarat-syarat yang harus dipenuhi antara lain:

a. Surat permohonan dalam bentuk rekomendasi yang ditujukan kepada Kepala Dinas Koperasi dan UMK Kota Semarang;

b. Fotocopy KTP domisili Kota Semarang;

c. Fotocopy ljin Usaha Mikro;

d. Melampirkan etiket merek yang akan didaftarkan.

Selanjutnya setelah semua persyaratan telah dipenuhi, pihak Dinas Koperasi dan UMK Kota Semarang akan mengeluarkan surat dalam bentuk surat rekomendasi yang di tanda tangani oleh Kepala Pemerintah Daerah Kota Semarang. Kemudian setelah mendapatkan surat rekomendasi dari Dinas Koperasi dan UMK Kota Semarang, pelaku usaha ekraf secara pribadilah yang akan mendaftarkan mereknya ke Kantor Wilayah Kementerian Hukum dan HAM Provinsi Jawa Tengah yang selanjutnya akan dikirimkan ke Dirjen HKI untuk diproses pendaftaran mereknya dan akan dibuatkan sertifikat merek (Dahlan, 2019). Dalam mendaftarkan merek melalui Kemenkumham, pelaku usaha ekraf harus memenuhi beberapa persyaratan yang telah ditentukan. Menurut Bapak Hawary selaku Kepala Sub Bidang Kekayaan Intelektual Kantor Wilayah Kemenkumham Provinsi Jawa Tengah, syarat-syarat yang harus dipenuhi dalam pendaftaran merek di Kemenkumham antara lain sebagai berikut:

1. Fotokopi KTP pemilik merek; 
Jurnal Pembangunan Hukum Indonesia

Volume 2, Nomor 2, Tahun 2020
Program Studi Magister Ilmu Hukum Fakultas Hukum Universitas Diponegoro
2. Surat rekomendasi dari Pemerintah Daerah jika UMK tersebut binaan Pemerintah Daerah;

3. Spesimen tanda tangan dalam kertas A4/F4;

4. Mengisi formulir pendaftaran yang dapat diunduh di www.dgip.go.id;

5. Etiket merek ukuran $20 \times 25 \mathrm{~cm}$ dalam 1 (satu) lembar kertas A4/F4;

6. Surat kuasa jika melalui kuasa.

Berkaitan dengan biaya pendaftaran merek, jika usaha ekraf tersebut tergolong Usaha Mikro dan Kecil binaan Pemerintah Daerah yang dibuktikan melalui adanya surat rekomendasi dari Pemerintah Daerah, akan mendapatkan keringanan biaya pendaftaran dibandingkan dengan kategori pelaku usaha umum. Yakni bagi Usaha Mikro dan Kecil biaya pendaftaran merek yang dikeluarkan sebesar Rp. 500.000,00 (pendaftaran secara online) dan Rp. $600.000,00$ (pendaftaran secara manual), namun jika usaha tersebut masuk dalam kategori umum akan dikenakan biaya sebesar Rp. 1.800.000,00 (pendaftaran secara online) dan Rp. 2.000.000,00 (pendaftaran secara manual). Hal ini sesuai dengan yang diatur dalam Peraturan Pemerintah Republik Indonesia No. 28 Tahun 2019 tentang Jenis dan Tarif Atas Jenis Penerimaan Negara Bukan Pajak Yang Berlaku Pada Kementerian Hukum dan Hak Asasi Manusia mengenai biaya pendaftaran merek.

Prosedur pendafataran merek dalam UndangUndang No. 20 Tahun 2016 Tentang Merek dan Indikasi Geografis menjadi lebih singkat dengan memerlukan waktu 8 (delapan) bulan dibandingkan dengan Undang-Undang Merek yang lama yakni
Undang-Undang No. 15 Tahun 2001 Tentang Merek yang memerlukan waktu lebih lama yaitu 14 (empat belas) bulan 10 (sepuluh) hari. Penyederhaan prosedur pendaftaran merek pada Undang-Undang No. 20 Tahun 2016 Tentang Merek dan Indikasi Geografis akan mempercepat pemohon dalam mendapatkan nomor pendaftaran dari sebelumnya.

Berikut penulis sajikan skema prosedur pendaftaran merek sebagai berikut:

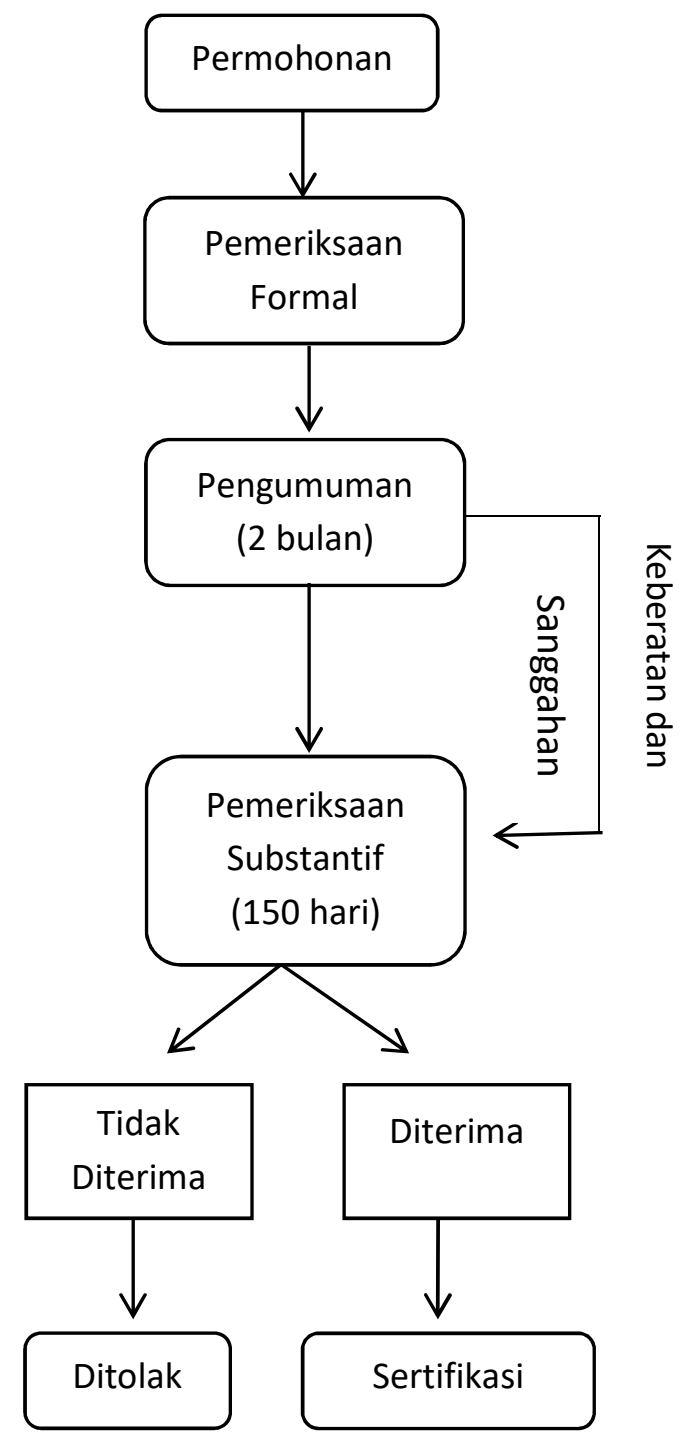

Berdasarkan implementasi pendaftaran merek pada komunitas penghasil produk ekraf yang menjadi 
Jurnal Pembangunan Hukum Indonesia

Volume 2, Nomor 2, Tahun 2020
Program Studi Magister Ilmu Hukum Fakultas Hukum Universitas Diponegoro responden penulis, perlindungan hukum yang diberikan terhadap implementasi pendaftaran merek tersebut menganut sistem konstitutif dengan prinsip first to file (Hidayah, 2017).

Hal ini dimaksudkan bahwa merek baru akan mendapatkan perlindungan apabila merek tersebut sudah didaftarkan ke pemerintah melalui Kementerian Hukum dan HAM. Jadi apabila pelaku usaha produk ekraf yang menggunakan suatu merek atas produknya namun tidak atau belum didaftarkan, maka pelaku usaha ekraf tersebut akan kehilangan perlindungan hukum terhadap mereknya. Perlindungan hukum terhadap merek terdaftar dimaksudkan guna memberikan suatu hak eksklusif bagi si pemegang merek agar mereknya tidak digunakan oleh pihak lain baik merek yang sama ataupun mirip dengan yang dimilikinya untuk barang yang sama maupun barang yang hampir sama. Hak eksklusif tersebut hanya dapat digunakan oleh si pemegang merek dan tidak boleh melanggar aturanaturan dalam penggunaan merek serta melarang pihak lain jika ada yang menggunakan mereknya tanpa izin si pemegang merek (Nurcahya, 2014). Perlindungan merek terdaftar khususnya terhadap produk-produk ekraf dapat memberikan suatu manfaat salah satunya yaitu dapat menghasilkan income, meningkatkan jaminan produk-produk ekraf, meningkankan daya saing dan mendapatkan perlindungan terhadap merek dagangnya (Kowel, 2017).
Perlindungan hukum menurut Satjipto Raharjo dapat dibedakan menjadi 2 (dua) antara lain sebagai berikut:

\section{a. Perlindungan Hukum Preventif}

Perlindungan hukum preventif adalah perlindungan hukum yang diberikan oleh pemerintah yang bertujuan untuk mencegah sebelum terjadinya pelanggaran. Berkaitan dengan perlindungan hukum preventif (Raharjo, 1983). Sebuah merek yang telah terdaftar diberikan perlindungan yang bertujuan agar orang lain tidak tidak dapat menggunakan merek tersebut. Sebagaimana yang telah diatur dalam Pasal 35 Undang-Undang No. 20 Tahun 2016 Tentang Merek dan Indikasi Geografis bahwa Merek yang telah terdaftar akan mendapatkan perlindungan selama 10 (sepuluh) tahun dari tanggal penerimaan pendaftaran. Jangka waktu perlindungan merek dapat diperpanjang untuk masa yang tidak ditentukan selama 10 (sepuluh) tahun dengan melakukan pembayaran biaya. Dalam hal ini, pemilik merek harus melakukan pengajuan perpanjangan merek 12 (dua belas) bulan sebelum berakhirnya jangka waktu merek tersebut. Masa berlakunya merek hanya akan diperpanjang jika pemilik merek masih menggunakan merek tersebut dalam kegiatan perdagangan barang maupun jasa (Lindsey, 2010). Jika permohonan perpanjangan dilakukan setelah jangka waktu perlindungan merek berakhir, permohonan perpanjangan akan dikenai biaya dan denda sebesar biaya perpanjangan. Hal ini sesuai dengan yang telah diatur dalam Pasal 35 ayat (4) Undang-Undang No. 20 Tahun 2016 tentang Merek dan Indikasi 
Jurnal Pembangunan Hukum Indonesia

Volume 2, Nomor 2, Tahun 2020
Program Studi Magister Ilmu Hukum Fakultas Hukum Universitas Diponegoro
Geografis. Jika selama 6 bulan setelah jangka waktu perlindungan merek berakhir namun pemilik merek tetap tidak melakukan perpanjangan perlindungan terhadap mereknya maka merek tersebut bukan lagi menjadi milik si pemilik merek. Merek tersebut dapat didaftarkan oleh orang atau badan hukum lain karena telah hilangnya perlindungan merek pada si pemilik merek sebelumnya.

\section{b. Perlindungan Hukum Represif}

Perlindungan hukum represif merupakan perlindungan hukum yang terakhir dilakukan yakni dengan memberikan hukuman ataupun sanksi berupa denda, penjara, dan hukuman tambahan. Hukuman tersebut dierikan setelah terjadinya sengketa atau setelah dilakukannya suatu pelanggaran. Pada dasarnya perlindungan hukum yang diberikan terhadap merek terdaftar yakni guna mencegah terjadinya unfair competition. Dengan digunakannya sistem konstitutif dalam pendaftaran merek, maka unfair competition atau persaingan usaha tidak sehat dapat dicegah. Hal ini dikarenakan karena dengan digunakannya sistem konstitutif dapat menimbulkan kepastian hukum terhadap perlindungan hukum merek terdaftar. Perlindungan hukum tersebut memberikan hak kepada pemilik merek guna menuntut para pihak yang telah melakukan pelanggaran merek (Chuzaibi, 2011).

Perlindungan hukum yang diberikan dalam implementasi pendaftaran merek terhadap produkproduk ekraf telah sesuai dengan teori perlindungan hukum di bidang merek yang telah dikemukakan oleh Robert yakni Reward Theory, Recovery Theory, Risk
Theory, Incentive Theory dan Economic Growth Stimulus Theory (Sherwood, 1990). Namun perlindungan hukum yang diberikan belum sepenuhnya dilaksanakan secara optimal. Dapat ditunjukkan bahwa faktanya sampai saat ini masih banyak merek yang mempunyai persamaan pada pokoknya maupun keseluruhannya dengan merek pihak lain yang telah terdaftar namun lolos dalam tahap pemeriksaan substantif saat proses pendaftaran merek karena dianggap manusiawi dan diberikan kompensasi. Misalnya saja pada Merek PT. Krakatau Steel dimana ia lebih dahulu terdaftar pada Dirjen HKI yaitu: Merek "KS" pada tanggal 17 Juni 2004, Merek "Krakatau Steel + LOGO" pada tanggal 12 Februari 2004, dan Merek "KS POLE" pada tanggal 01 Agustus 1997. Merek-merek tersebut di atas adalah merek terdaftar milik PT. Krakatau Steel, namun Dirjen $\mathrm{HKI}$ masih mengeluarkan atau memberikan kepada PT. Perwira Adhitama Sejati. Seharusnya Dirjen HKI melakukan pencegahan dengan menolak pengajuan pendaftaran yang diajukan oleh PT. Perwira Adhitama Sejati tersebut karena sudah ada merek lain yang memiliki unsur persamaan pada pokoknya atau keseluruhannya. Selain itu, menurut Bapak Hawary selaku pihak Kementerian Hukum dan HAM Provinsi Jawa Tengah, pada tahun 2018 pernah ada sengketa pelanggaran merek mengenai adanya persamaan pada pokoknya terhadap merek milik orang lain yang sudah terlebih dahulu didaftarkan. Persamaan ada pada pokoknya antara merek AZIS dengan merek ASIS. Merek tersebut ditolak oleh pemeriksa namun 
Jurnal Pembangunan Hukum Indonesia

Volume 2, Nomor 2, Tahun 2020
Program Studi Magister Ilmu Hukum Fakultas Hukum Universitas Diponegoro saat kasus tersebut sampai di Pengadilan Niaga, Pengadilan Niaga memutuskan bahwa merek tidak terdapat persamaan pada pokoknya terhadap merek tersebut. Hakim memutuskan bahwa antara huruf $Z$ dan huruf $\mathrm{S}$ itu berbeda maknanya.

Padahal di dalam Pasal 21 ayat (2) UndangUndang No. 20 Tahun 2016 tentang Merek dan Indikasi Geografis sudah jelas diatur bahwa jika merek tersebut terdapat persamaan baik pada pokoknya maupun keseluruhannya merek tersebut harus ditolak pendaftarannya. Dalam menentukan ada tidaknya persamaan pada pokoknya antara merek yang satu dengan merek yang lain, maka atas merek-merek bersangkutan harus dipandang secara keseluruhan sebagai satu kesatuan yang bulat, tanpa mengadakan pemecahan atas bagian dari merekmerek tersebut. Lemahnya perlindungan terhadap merek pada produk-produk ekraf dilatarbelakangi karena kurangnya pemahaman masyarakat bahwa delik pidana yang terdapat dalam Undang-Undang di bidang HKI merupakan delik aduan, artinya jika terjadi suatu pelanggaran merek, jika pemegang hak merek tidak melakukan pengaduan kepada pihak penegak hukum maka perkara tersebut tidak akan ditindaklanjuti oleh penegak hukum (Dahlan, 2019).

Dalam hal terjadinya pelanggaran merek, sarana dalam perlindungan secara represif juga terdapat pada Pasal 28 sampai dengan Pasal 32 Undang-Undang No. 20 Tahun 2016 Tentang Merek dan Indikasi Geografis megenai pengaturan permohonan Banding, serta adanya lembaga independen yakni Komisi Banding Merek yang berwenang untuk memeriksa permohonan keberatan atas merek yang dimohonkan haknya dan permohonan banding atas penolakan permohonan pendaftaran Merek. Hal ini sesuai dengan ketentuan dalam Pasal 33 dan Pasal 34 Undang-Undang No. 20 Tahun 2016 Tentang Merek dan Indikasi Geografis. Jika terjadi pelanggaran merek, berdasarkan Pasal 83 Undang-Undang No. 20 Tahun 2016 Tentang Merek dan Indikasi Geografis dapat mengajukan gugatan ganti rugi kepada Pengadilan Niaga. Ketentuan pidana yang dapat diterapkan jika terjadi pelanggaran merek berdasarkan Pasal 100 Undang-Undang No. 20 Tahun 2016 Tentang Merek dan Indikasi Geografis.

2. Hambatan-Hambatan Yang Dihadapi Dalam Perlindungan Merek Terdaftar Bagi Komunitas Penghasil Produk Ekonomi Kreatif (ekraf) Dan Upaya Dalam Mengatasi Hambatan Tersebut

Pendaftaran merek suatu merek selalu dihadapkan dengan banyaknya hambatan-hambatan yang terjadi, khususnya terhadap pendaftaran merek pada produk-produk ekraf di Kota Semarang. Mengingat bahwa produk-produk ekraf sebagian besar adalah tergolong Usaha Mikro dan Kecil (UMK), dimana karakteristik Usaha Mikro dan Kecil (UMK) adalah suatu usaha kecil yang memiliki kelemahan dari sisi ekonomi maupun keterbatasan pengetahuan terhadap merek terutama mengenai pentingnya merek pada produk dagangnya, mekanisme dan prosedur pendaftarannya serta kesadaran pelaku usaha ekraf untuk melindungii produk ekrafnya. Berdasarkan hasil wawancara dari 
Jurnal Pembangunan Hukum Indonesia

Volume 2, Nomor 2, Tahun 2020
Program Studi Magister Ilmu Hukum

Fakultas Hukum Universitas Diponegoro beberapa informan di atas, menjelaskan mengenai hambatan-hambatan yang mereka hadapi dalam implementasi pendaftaran merek miliknya. Hasil dari penelitian ini menjelaskan bahwa terdapat hambatanhambatan yang dihadapi oleh para pelaku usaha ekraf yang menyebabkan masih rendahnya minat mereka dalam mendaftarkan merek pada produknya antara lain:

\section{a. Hambatan Internal}

Hambatan internal merupakan hambatan yang muncul pada dari pihak komunitas penghasil produk ekonomi kreatif di Kota Semarang itu sendiri. Hambatan internal dalam implementasi pendaftaran merek bagi komunitas penghasil produk ekraf dilatarbelakangi oleh beberapa faktor yaitu: Keterbatasan pengetahuan pelaku usaha ekraf dalam hal pentingnya perlindungan HKI khususnya Merek serta kurangnya pengetahuan mengenai prosedur pendaftaran mereknya; kurangnya informasi yang didapat melalui penyuluhan dan sosialisasi; keterbatasan dana; dan pelaku usaha ekraf beranggapan bahwa usahanya masih belum maju dan tergolong usaha kecil sehingga tidak perlu didaftarkan (Andrew \& Samosir, 2018).

\section{b. Hambatan Eksternal}

Selain hambatan-hambatan internal yang dihadapi oleh para pelaku usaha ekraf dalam implementasi pendaftaran mereknya, terdapat hambatan-hambatan eksternal yang berasal dari luar komunitas penghasil produk ekraf di Kota Semarang. Hambatan-hambatan eksternal dapat berupa antara lain: keterbatasan pemerintah baik pihak Dinas
Koperasi dan UMK Kota Semarang maupun Kementerian Hukum dan HAM dalam memberikan perlindungan terhadap HKI oleh pelaku usaha ekraf; biaya administrasi pendaftaran merek yang mahal; lemahnya jaminan kepastian hukum bagi pelaku usaha ekraf untuk mendapatkan sertifikat hak merek; dan penggunaan nama Merek yang masih banyak terdapat permasamaan pada pokoknya maupun keseluruhannya terhadap merek orang lain yang lebih dahulu terdaftar.

Berdasarkan hambatan-hambatan yang dihadapi baik oleh para pelaku usaha ekraf maupun instansi sebagai pihak yang terkait dalam masalah pendaftaran merek, maka perlu dilakukan suatu suatu upaya untuk mengatasi hambatan-hambatan tersebut. Upaya-upaya yang dapat dilakukan guna mengatasi hambatan-hambatan dalam pendaftaran merek pada produk-produk ekraf yakni dengan cara antara lain: meningkatkan kegiatan sosialisasi maupun penyuluhan mengenai HKI khususnya di bidang merek kepada para pelaku usaha ekraf; memfasilitasi pembiayaan terhadap pendaftaran Merek bagi komunitas penghasil produk ekraf; melakukan kerjasama antara Dirjen Kekayaan Intelektual Kementerian Hukum dan HAM dengan Dinas Koperasi dan Usaha Mikro dan Kecil (UMK); memberikan pengarahan kepada para pelaku ekraf yang akan mendaftarkan merek produknya untuk langsung mendaftarkan mereknya melalui Kementerian Hukum dan HAM; pendaftaran merek secara kolektif bagi komunitas penghasil produk 
Jurnal Pembangunan Hukum Indonesia

Volume 2, Nomor 2, Tahun 2020
Program Studi Magister Ilmu Hukum Fakultas Hukum Universitas Diponegoro ekraf dan mendaftarkan merek secara online melalui website resmi Kementerian Hukum dan HAM.

Sebenarnya yang membuat anggapan masyarakat bahwa mekanisme pendaftaran merek itu mahal dan rumit adalah kebanyakan dari mereka mempercayakan pendaftaran mereknya melalui oknum-oknum yang tidak mempunyai kewenangan sama sekali dalam pendaftaran merek. Oknumoknum tersebut sudah dapat dipastikan akan mematok biaya lebih mahal dari biaya yang telah ditentukan oleh Kementerian Hukum dan HAM untuk proses pendaftaran merek miliknya. Oleh karena itu sebaiknya jika ingin mendaftarkan merek bisa langsung datang ke kantor Kementerian Hukum dan HAM maupun dengan mendaftarkan mereknya langsung melalui website resmi Kementerian Hukum dan HAM. Pihak Kementerian Hukum dan HAM sangat terbuka memberikan informasi kepada pendaftar merek yang membutuhkan bantuan dalam pendaftaran mereknya.

Berdasarkan upaya-upaya yang dilakukan untuk mengatasi hambatan-hambatan mengenai implementasi pendaftaran merek pada produkproduk ekraf, dapat dilihat bahwa peran instansi terkait seperti Kemenkumham dan Dinkop Kota Semarang dalam hal perlindungan merek terdaftar pada produk-produk ekraf belum dijalankan secara optimal. Penyuluhan serta sosialisasi yang diberikan kepada komunitas pelaku ekraf juga masih sangat minim. Pemerintah dan pemerintah daerah mempunyai tanggung jawab dalam melakukan pembinaan serta pengembangan UMK khususnya

yang berbasis kreativitas di wilayahnya. Berdasarkan Undang-Undang No. 3 Tahun 2014 Tentang Perindustrian menjelaskan bahwa tugas dan tanggung jawab pemerintah dan pemerintah daerah terkait dengan merek yang terdapat dalam Pasal 43 ayat (3) yaitu mengenai peran pemerintah dan pemerintah daerag dalam mengembangkan dan memanfaatkan kreativitas dan inovasi, khususnya dengan cara memberikan konsultasi, bimbingan serta advokasi perlindungan hak kekayaan intelektual bagi usaha kecil. Pemerintah daerah berkewajiban untuk membangun, memberdayakan, serta memfasilitasi perlidungan HKI pada UMK yang didalamnya termasuk hak atas merek. Dalam Pasal 14 ayat (1) huruf a Undang-Undang No. 20 Tahun 2008 Tentang Usaha Mikro, Kecil dan Menengah juga dijelaskan bahwa dalam hal menumbuhkan iklim usaha serta memberikan fasilitasi untuk pengembangan usaha, Pemerintah dan Pemerintah Daerah memberikan fasilistasi kepemilikan HKI atas produk serta desain Usaha Mikro, Kecil dan Menengah dalam menjalankan kegiatan usaha baik dalam negeri maupun ekspor dan dapat mendorong UMK untuk memperoleh sertifikat HKI. Terkait hal ini, perlunya melakukan kerjasama antara DJKI Kementerian Hukum dan HAM dengan Dinas Koperasi dan UMK. Kerjasama yang dilakukan oleh Dinas Koperasi dan UMK Kota Semarang guna meningkatkan pengembangan mengenai perlindungan $\mathrm{HKI}$ khususnya di bidang merek (Risky \& Munawar, 2019). 
Jurnal Pembangunan Hukum Indonesia

Volume 2, Nomor 2, Tahun 2020
Program Studi Magister Ilmu Hukum

Fakultas Hukum Universitas Diponegoro
Selain itu, pelaku ekraf juga mengeluhkan mengenai biaya pendaftaran merek bagi pelaku ekraf yang mana usaha mereka merupakan jenis Usaha Mikro dan Kecil. Didalam Undang-Undang No. 20 Tahun 2016 tentang Merek dan Indikasi Geografis memang secara tersirat tidak membedakan mengenai pendaftaran merek untuk jenis pelaku usaha ekraf yang masuk golongan Usaha Mikro dan Kecil (UMK) dengan jenis pelaku usaha lainnya. Hal ini telah sesuai dengan prinsip nondiskriminasi yang terdapat dalam TRIPs, dimana dalam prinsip Most Favoured Nations Trearment (MFN) menjelaskan bahwa dalam prinsip ini menekankan pada perlakuan yang sama untuk seluruh negara yang masuk dalam anggota WTO, dapat diartikan bahwa semua yang akan mendaftarkan hak mereknya harus memenuhi persyaratan, prosedur, serta biaya pendaftaran yang sama (Dharmawan, \& Wiryawan, 2014).

Penerapan sistem konstitutif terhadap semua pelaku usaha baik bagi pelaku usaha ekraf yang dapat dikatakan tergolong pihak yang lemah maupun bagi pelaku usaha lainnya yang lebih kuat, dianggap belum mencerminkan keadilan. Hal ini disebabkan karena dengan kebijakan menyamaratakan semua persyaratan, prosedur serta biaya pendaftaran merek dianggap sangat memberatkan pelaku usaha ekraf. Oleh karena itu, pemerintah membuat kebijakan mengenai pembedaan tariff PNBP Merek yang diatur dalam Peraturan Pemerintah Republik Indonesia No. 28 Tahun 2019 tentang Jenis dan Tarif Atas Jenis Penerimaan Negara Bukan Pajak Yang Berlaku Pada Kementerian Hukum dan Hak Asasi Manusia.
Kebijakan ini sesuai dengan pendapat Salmond yang dijelaskan oleh Fitzgerald dimana hukum mempunyai tujuan untuk mengintegrasikan serta mengkoordinasikan berbagai kepentingan yang ada dalam masyarakatnya (Muin, 2015). Kebijakan mengenai pembedaan tariff PNBP yang dibuat oleh pemerintah tersebut disau sisi bertentangan dengan prinsip TRIPs, namun disisi lain dengan adanya kebijakan perbedaan tarif PNPB merek tersebut, menunjukkan bentuk keberpihakan pemerintah guna melindungi UMK khususnya yang berbasis ekraf (Faiz, 2010). Hal ini sesuai dengan teori keadilan yang dikemukakan oleh John Rawls dimana disebutkan apabila terdapat kondisi ketidaksetaraan maka perlakuan khusus harus diberikan terhadap pihak yang lemah (Chuzaibi, 2011).

\section{SIMPULAN}

Ekonomi kreatif merupakan salah satu sektor ekonomi yang sedang mendapatkan perhatian yang besar dari pemerintah. Produk-produk yang dihasilkan oleh ekraf tidak akan pernah terpisah dari Kekayaan Intelektual didalamnya khususnya Merek. Merek yang melekat pada produk tersebut umumnya mempunyai nama tersendiri sebagai identitas dari produk dan pembeda dalam membedakan produk tersebut dengan produk yang lain. Hak atas merek yang dimiliki oleh seseorang atau badan hukum baru akan terjadi setelah merek tersebut terdaftar di Direktorat Jenderal Hak Kekayaan Intelektual (DJKI) Kementerian Hukum dan Hak Asasi Manusia. Berdasarkan beberapa sample responden dalam 
Jurnal Pembangunan Hukum Indonesia

Volume 2, Nomor 2, Tahun 2020
Program Studi Magister Ilmu Hukum

Fakultas Hukum Universitas Diponegoro penelitian ini menunjukkan bahwa memang pada kenyataannya masih banyak pelaku ekraf yang belum mendaftarkan merek produknya dan belum mengetahui secara luas mengenai pentingnya perlindungan merek terdaftar serta prosedur pendaftaran merek terhadap produk-produk ekraf miliknya. Produk-Produk ekraf sangat rentan terhadap tindak unfair competition, oleh karena itu perlindungan hukum terhadap merek perlu diberikan melalui perlindungan secara preventif dan perlindungan hukum secara represif yang diberikan oleh pihak instansi terkait permasalahan mengenai pendaftaran merek seperti Kementerian Hukum dan HAM dan Dinas Koperasi dan UMK.

Dalam hal implementasi pendaftaran merek masih banyaknya hambatan-hambatan yang dihadapi oleh para pelaku ekraf serta minimnya fasilitas yang diberikan oleh Pemerintah dan Pemerintah Daerah kepada pelaku ekraf dalam memperoleh perlindungan mereknya. Hambatanhambatan yang dihadapi dalam hal perlindungan merek melalui pendaftaran merek dapat berupa hambatan internal dan hambatan eksternal. Penyederhanaan proses pendaftaran merek yang dalam praktiknya masih memakan waktu yang relative lama, sehingga dapat mengurangi minat para pelaku ekraf dalam mendaftarkan mereknya. Dengan adanya hambatan-hambatan tersebut, maka diperlukan adanya upaya-upaya dalam mengatasi berbagai hambatan-hambatan yang muncul. Upayaupaya yang telah diberikan diharapkan mampu mendorong dalam meningkatan pelaku ekraf untuk mendaftarkan merek produknya sehingga terhindar dari terjadinya pelanggaran HKI khususnya merek.

\section{DAFTAR PUSTAKA}

\section{BUKU}

Fauzan, Uzair., \& Prasetyo, Heru. (2006). Teori Keadilan John Rawls. Yogyakarta: Pustaka Pelajar.

Hidayah, K. (2017). Hukum Hak Kekayaan Intelektual, Jakarta: Setara Press.

Lindsey, T. (2010). Hak Kekayaan Intelektual. Bandung: Alumni.

Rahardjo, S. (2010). Permasalahan Hukum di Indonesia. Bandung: Alumni.

Raharjo, S. (2010). Sisi-Sisi Lain dari Hukum di Indonesia. Jakarta: Kompas.

Sherwood, Robert M. (1990). Intellectual Property and Economic Development, Virginia: Alexandria.

\section{J URNAL}

Andrew, Betlehn., \& Samosir, Prisca. (2018). Upaya Perlindungan Hukum Terhadap Merek Industri UMKM di Indonesia. Jurnal Law and J ustice, Vol.3, (No.1). pp. 615-630.

Chuzaibi, F. (2011). Sistem Konstitutif Dalam Undang-Undang No. 15 Tahun 2001 Tentang Merek Bagi UMKM. Jurnal Syiar Hukum, Vol.XIII, (No.2). pp. 152-167.

Dharmawan, Ni Ketut Supasti., \& Wiryawan, Wayan. (2014). Keberadaan dan Implikasi Prinsip MFN dan NT Dalam Pengaturan Hak Kekayaan 
Intelektual Di Indonesia. Jurnal Magister Hukum Udayana, Vol.6, (No.2). pp. 259-275.

Faiz, P. (2010). Teori Keadilan John Rawls. Jurnal Konstitusi, Vol.6, (No.1). pp. 135-149.

Greene, S. (2011). Protecting Well-Known Marks in China: Challenges for Foreign Mark Holders. American Bussiness Law Journal, Vol.45 (No.2), pp. 371-398.

Ingram, Keisha L. (2014). Intellectual Property Protection for Brand Jamaica's Creative Industries. Socialines Technologies Journal, Vol.4 (No.1), pp. 151-167.

Kowel, F. (2017). Perlindungan Hukum Terhadap Penerima Lisensi Merek Di Indonesia. Jurnal Lex et Societatis, Vol.5 (No.3). p.55.

Kurniati, Nia., Permata, Ratna., Hindersah, Reginawanti., Kuswaryan, Sondi., \& Souisa, Yongki. (2017). Perlindungan Kekayaan Intelektual terhadap Produk Teri Seira dan Kerupuk Ikan Tanimbar sebagai Industri Kreatif Masyarakat di Kota Sumlaki. Jurnal PJ IH, Vol.4 (No.3), pp. 515-531.

Muin, F. (2015). Perlindungan Hukum Terhadap Tenaga Kerja Indonesia (Tinjauan Terhadap Undang-Undang No. 39 Tahun 2004 Tentang Penempatan Dan Perlindungan Tenaga Kerja Indonesia). J urnal Cita Hukum, Vol.III, (No.1). p. 18.

Nurcahya, F. (2014). Perlindungan Hukum Bagi Hak Atas Merek Terhadap Perbuatan Pelanggaran Merek. Mimbar Keadilan; J urnal IImu Hukum, p. 340.
Risky., \& Munawar. (2019). Studi Perlindungan Hukum Merek Pada Usaha Kecil Menengah (UKM) Jenang Di Kabupaten Ponorogo Dalam Upaya Mendukung Berkembangnya Ekonomi Kreatif. J urnal Privat Law, Vol.VII, (No.1). PP. 213-230.

Rois, Muhammad Fahmi., \& Roisah, Kholis. (2018). Perlindungan Hukum Kekayaan Intelektual Kerajinan Kuningan Tumang. Kanun Jurnal Ilmu Hukum, Vol.20, (No.3), pp. 354-367.

Rongiyati, S. (2018). Perlindungan Hukum Hak Kekayaan Intelektual Pada Produk Ekonomi Kreatif. J urnal Negara Hukum, Vol.9 (No.1), p. 40.

Rosmadi, Maskoto L. (2014). Industri Kreatif dalam Menghadapi Pasar Bebas ASEAN Tahun 2015. Jurnal Wawasan Hukum, Vol.30 (No.1), pp.97-106.

Sardjono, A. (2013). Pelaksanaan Perlindungan Hukum Merek Untuk Pengusaha UKM Batik Di Pekalongan, Solo, dan Yogyakarta, Jurnal Hukum dan Pembangunan, Vol.4. p. 442.

Sardjono, Agus., Prastyo, Brian Amy., Larasati Desrezka Gusti. (2013). Pelaksanaan Perlindungan Hukum Merek Untuk Pengusaha UKM Batik di Pekalongan. J urnal Hukum dan Pembangunan, Vol.44 (No.4), pp. 496-518. Yulianto, Irwan., \& Uraidi, Ali. (2018). Peningkatan Potensi Batik Melalui Perlindungan Hak Kekayaan Intelektual. Conference on Innovation and Application of Scien and Technology, Vol.5. pp. 141-148. 


\section{WAWANCARA DAN SUMBER LAINNYA}

Dahlan, H. (2019). Kepala Sub Bidang Kekayaan Intelektual Kantor Wilayah Kementerian Hukum dan HAM Provinsi Jawa Tengah. Pada Tanggal 27 Desember 2019 di Kementerian Hukum dan HAM Provinsi Jawa Tengah.

Irawati, T. (2019). Pemilik Merek Bel_Incraft. Pada Tanggal 13 Desember 2019 Di Semarang. 